\title{
Does the Tail Wag the Dog? Early Presidential Nomination Polling in New Hampshire and the U.S.
}

\author{
Dante J. Scala and Andrew E. Smith
}

The authors examine whether early state polls, particularly New Hampshire, have been more accurate in predicting the eventual presidential nominees. The authors conclude that New Hampshire poll results have become better bellwethers and propose that the more informed nature of the state's electorate may be a reason for the accuracy of the results.

"The polls went up for Hillary and the open attacks on her have begun. Related? In politics it usually is," confidently asserted Mark Penn, Hillary Clinton's chief strategist, in August 2007. ${ }^{1}$ What polls made Penn so confident? Surveys of the national Democratic primary electorate. "The latest round of national polls last week-from Newsweek and NBC/Wall Street Journal-have shown Hillary making significant gains on two frontsconsolidating her lead among the Democratic primary electorate nationwide and advancing in the general election against likely Republican nominees," wrote Penn. In all, the strategist mentioned five different national polls before citing a single poll in Iowa or New Hampshire. Attacks on Clinton, Penn stated, were "the result of the first six months of campaigning and the voters taking a good hard look at all the candidates and concluding that Hillary has what it takes to be President and what it takes to take on the Republicans" (emphasis added). According to Penn, national polls in the pre-primary year were indeed "hard numbers," reflecting the results of national Democratic primary voters' deliberations.

On the very same day, the campaign manager for Barack Obama, Clinton's chief opponent for the Democratic nomination, altogether dismissed the importance of national polls. "As the Washington insiders focus on irrelevant and wildly inconsistent national polls, there are strong signs in Iowa, New Hampshire and South Carolina of the growing power and potential of this candidacy," David Plouffe wrote. He added:

\footnotetext{
The authors wish to thank Louisa K. Brown for valuable research help; the New Hampshire Institute of Politics at Saint Anselm College; and Andrew Dowdle, Barbara Norrander, and Wayne Steger for their advice and comments.

DANTE J. SCALA is an associate professor of political science at the University of New Hampshire. ANDREW E. SMITH is an associate professor of political science at the University of New Hampshire and director of the University of New Hampshire's Survey Research Center.
}

The American Review of Politics, Vol. 28, Winter, 2007-2008: 401-424

(c)2007 The American Review of Politics 
The national press continues to be obsessed about national primary polling, but as we outlined in the last memo, we fundamentally reject the importance of these national primary polls. This is a sequential process that begins in Iowa and carries through the calendar. If national polls were affecting our ability to grow the campaign, perhaps we would pay them some attention. But they have not, so we don't (emphasis added).

We submit that the two campaigns' differing assessments of the importance of national polling, vis-à-vis early state polling, had something to do with where their candidates stood in those two sets of polls. (To be fair, however, Plouffe also stated that early state polls are also "poor predictors" at this stage of the primary season.) Nonetheless, their disagreement raises an important question in presidential primary polling: Do early polls of national primary electorates (those conducted in the calendar year prior to the election year) offer accurate forecasts of eventual nomination outcomes? Or does the opinion of the national primary electorate actually develop sequentially - first in the early caucus and primary states, and only after that among the national electorate?

Specifically, have early state polls, particularly New Hampshire, been more accurate in predicting the eventual nominee? Are New Hampshire polls indeed more sensitive to campaign fluctuations because of a more informed electorate? These are the questions this research seeks to address in this research.

There have been no studies that have directly tested the question of whether New Hampshire or national polls are better predictors of the eventual nominee. John (1989) examined the accuracy of final tracking polls in the New Hampshire primary, but did not discuss the pre-primary phase of the campaign. There is considerable research that indicates that national media coverage is determined by national poll standing (Adams 1987; Lichter, Amundson, and Noyes 1988; Steger 2002). Perhaps a similar phenomenon occurs in New Hampshire polling: Are New Hampshire polls attracting national news coverage, thus propelling lesser known candidates who might be doing well in the Granite State to achieve similar standing in national polls?

Several studies have lent support to the early state hypothesis with proof that winning the New Hampshire primary was a strong indicator of winning the eventual nomination (Adams 1987; Adkins and Dowdle 2001). And the fact that so many candidates run early-state campaigns is a strong indicator that for those for whom it matters most, winning early states is seen as critical to clinching the nomination (e.g., Bartels 1988).

But while many candidates see the value of running an early state campaign, there is a considerable body of evidence that demonstrates that a candidate's position in national polls is perhaps the strongest indicator of 
success in capturing the nomination (Aldrich 1980; Marshall 1983; Norrander 1986; Bartels 1988; Mayer 1996, 2003). And several candidates in recent years have run "national" campaigns, including Walter Mondale (1984), John Glenn (1988), George W. Bush (2000), and Hillary Clinton and Rudy Giuliani in 2008.

While we do not specifically test whether running a national campaign is more effective than running an early-state campaign, we will speculate that there is a linkage between perceived success in early state polls and success in national polls.

\section{Hypotheses}

In this paper, we will test four hypotheses concerning national and New Hampshire polls.

$\boldsymbol{H}_{1}$ : New Hampshire polls will identify the winner of the New Hampshire primary before national polls.

$\boldsymbol{H}_{2}$ : New Hampshire polls will identify the eventual winner of the nomination before national polls.

$\boldsymbol{H}_{3}$ : National polls will lag behind New Hampshire polls, that is, a candidate will move up or down in trial heats in New Hampshire before they move up or down in national polls.

$\boldsymbol{H}_{4}$ : New Hampshire polls will identify the main alternative to the eventual winner of the nomination before national polls.

We expect that polls in New Hampshire will detect movement in the nomination horserace for several reasons: voters in New Hampshire are exposed to more in person campaigning by presidential candidates, increasing their likelihood of being confronted directly with campaign information; New Hampshire voters are much more likely to be exposed to news about the candidates via local television, newspaper and radio; therefore New Hampshire voters are "paying more attention" to the nomination campaign than are national voters. We speculate that a candidate who begins to improve in New Hampshire polls will attract additional media attention as reporters seek to find out why the candidate is improving. Voters across the country will then be exposed to these stories and would then be more likely to respond that they favor (or disfavor) a candidate because their awareness has been raised. 


\section{Data}

The data used in this study come from national media polling conducted during the 1980 through 2004 presidential election campaigns and from media and other non-candidate sponsored polls in New Hampshire. The time frame analyzed for each election was the calendar year prior to the election, from January to December. ${ }^{3}$

Only national media polls have been included. ${ }^{4}$ We included no polls conducted by parties or interest groups who might have an interest in a particular candidate winning the nomination. National polls used were collected from searches of the POLL database at the University of Connecticut Roper Center and from Polling Report (www.pollingreport.com). All of the national polls included in this analysis, with the exception of some Gallup polls in the 1980, 1984, and 1988 elections, were conducted by telephone; no web-based polls or polls not using a live interviewer were included. ${ }^{5}$

As might be expected, the number of national polls focused on the nomination has increased between 1980 and 2004. Only 17 national polls about preferences for the Democratic nomination were conducted in 1979 while 137 were conducted in 2008. A similar pattern is seen for the Republican nomination: 17 were conducted in 1979 and 149 were conducted in $2008 .^{6}$

For New Hampshire polls, we cast an even wider net, including not only media polls, but also polls conducted by the American Research Group (ARG) of Manchester, New Hampshire. ARG has conducted the New Hampshire Poll, "an independent poll that has surveyed New Hampshire residents on social, political, and economic issues on a regular basis since 1976." $" 7$

There are several potential problems using these data. First, the populations interviewed change from year to year and even during a single election year. Some polls were conducted with "likely primary voters," others used samples of self-defined registered partisans, while still others included both registered partisans and independents. ${ }^{8}$ Further complicating matters is that the definition of "likely voters" can vary widely between organizations and the methodologies used in identifying voters are not included in either the POLL database or in Polling Report. ${ }^{9}$

Another potentially significant problem concerns the wording of the questions used in these polls. They include open and closed-ended questions, questions that list all potential candidates including those who have not declared their candidacy, and questions which include only the names of the major declared candidates. Rademacher et al. (2001) and McDermott and Francovic (2003) argue that, at the conclusion of an election campaign, the wording of trial heat questions do not make much difference. But research 
has not been done to gauge the impact of question wording variations earlier in a campaign, when candidates are much less well known than during a general election, and in which there is also a lack of party cues for respondents to use to select candidates. ${ }^{10}$ The following example (Figure 1) of three polls conducted quite close to one another give a sense of the rather large differences in question wording.

Although there are several significant changes in wording between these questions (e.g., including the candidate's title or not; using "Dick" instead of "Richard" Gephardt; asking the respondent's choice versus who they would like to see nominated, etc.), the estimates generated by these three polls are all within sampling error of one another.

Despite the methodological concerns of combing disparate polls and disparate questions, we have been inclusive in selecting these questions for two reasons. First, all of these polls were reported by media organizations and were used by the sponsoring organization. Despite the form differences, consumers of news would be exposed to a similar message about the "meaning" of the poll as a gauge of the race at that time. A second, more practical

\section{Table 1. Examples of Different Question Wording}

"If you had to choose right now, which of these candidates would be your first choice as the Democratic candidate for President ... Reverend Jesse Jackson, Governor Michael Dukakis, Senator Albert Gore, Senator Paul Simon, Congressman Richard Gephardt, or Governor Bruce Babbitt?" (Yankelovich Clancy Shulman for Time Magazine, October 22,1987$)^{11}$

"Who do you want the Democrats to nominate for President in 1988-Bruce Babbitt, Michael Dukakis, Dick Gephardt, Albert Gore, Jesse Jackson, or Paul Simon?" (CBS News / New York Times, October 27, 1987)

"Which of the following would you most like to see nominated as the Democratic Party's candidate for President in 1988 - Jesse Jackson, Michael Dukakis, Paul Simon, Albert Gore, Richard Gephardt, Bruce Babbitt?" (Gallup Organization, October 26, 1984)

\begin{tabular}{lccc}
\hline & Yankelovich & CBS / NYT & Gallup \\
\hline Jackson & $23 \%$ & $17 \%$ & $22 \%$ \\
Dukakis & $12 \%$ & $13 \%$ & $14 \%$ \\
Gore & $8 \%$ & $7 \%$ & $7 \%$ \\
Simon & $7 \%$ & $10 \%$ & $8 \%$ \\
Gephardt & $5 \%$ & $3 \%$ & $5 \%$ \\
Babbitt & $2 \%$ & $2 \%$ & $1 \%$ \\
None / Not Sure / Undecided / Other & $44 \%$ & $48 \%$ & $43 \%$ \\
$(\mathrm{~N}=)$ & $(810)$ & $(1,326)$ & $(1,569)$ \\
\hline
\end{tabular}


reason is to increase the number of included polls for a more sensitive analysis.

This second concern is even more problematic when looking at just New Hampshire polls, particularly in early years. The number of New Hampshire polls has increased from seven Democratic and three Republican surveys in 1980 to 65 Democratic and 67 Republican polls in 2007. The lack of data points in New Hampshire is of particular concern as it is much more difficult to track changes in momentum during the campaign in New Hampshire than it is in the more frequently taken national polls.

The unit of analysis for this research is the month of the year. If more than one poll was conducted during a month, an average of the polls was used. Averaging monthly polls allows us to smooth over some of the differences that might occur because of the different methodologies used. ${ }^{12}$ The downside of averaging is that short-term changes in candidate support are hidden.

\section{Democratic Primary}

For most of the year prior to the 1980 primaries, President Jimmy Carter found himself trailing an opponent who had not even decided he was in the race for the Democratic nomination. Beleaguered by stagflation at home and the Iranian hostage crisis abroad, Carter was the choice of no more than 30 percent of national Democrats for most of calendar year 1979. Senator Edward Kennedy of Massachusetts, who had disappointed hopeful liberals by refusing to run for the presidency during the 1970 s, had the support of 50 percent of Democrats nationally until the end of 1979.

Carter regained the top spot in national polls before primaries and caucuses began, but the incumbent remained far behind Kennedy in early New Hampshire polling.

Public opinion among both national Democrats and New Hampshire Democrats remained static throughout 1979. The only significant change came in December 1979, when Carter surged past Kennedy in national polls. In New Hampshire, Carter did not move in front of Kennedy until a poll taken in January 1980 (Figure 1).

All in all, New Hampshire polling actually lagged behind national polling in terms of forecasting, although the very small number of polls taken in New Hampshire does hamper the study. Granite State polls even failed our most elementary test, whether they could predict the eventual winner of the New Hampshire primary before national polls did. Carter actually reversed his slide and regained the lead in national polls long before he recovered in New Hampshire; Kennedy's peculiar advantage of campaigning in his own backyard may have forestalled his slide in the Granite State. 
Figure 1. 1980 Democratic Primary

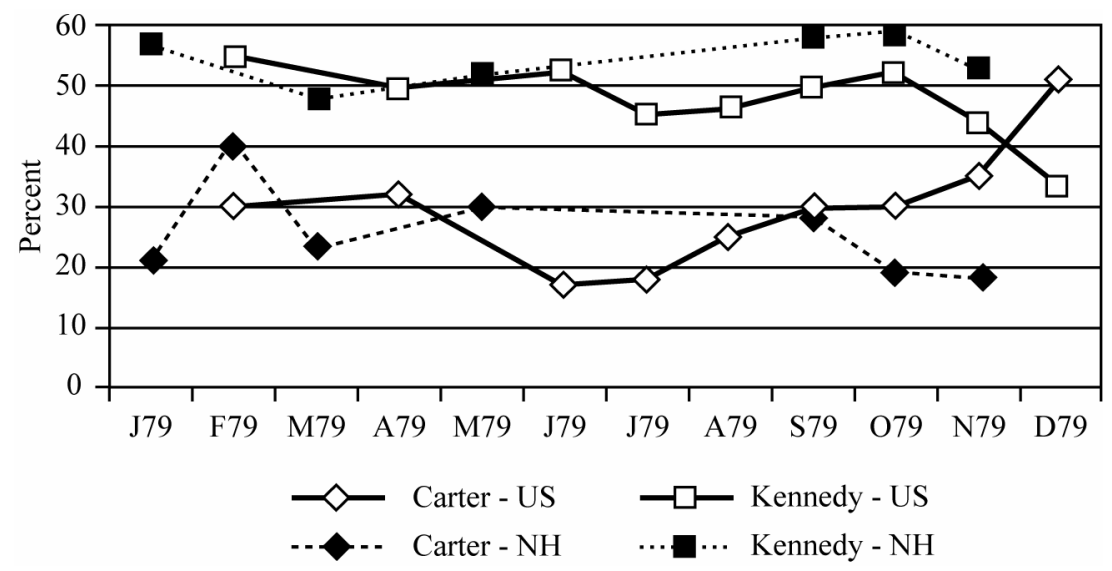

\section{Republican Primary}

The 1980 Republican primaries were a wide-open affair, albeit one with a heavily favored frontrunner. Ronald Reagan, the conservative insurgent who came very close to defeating incumbent President Gerald Ford for the Republican nomination in 1976, was the acknowledged frontrunner for the nomination in the year before the primaries began. He faced a field that included Sen. Howard Baker of Tennessee; former Texas governor John Connally; and former GOP chair and CIA Director George H.W. Bush. A possible Ford comeback was floated numerous times throughout 1979, but never came to fruition. Bush succeeded in upending Reagan in the Iowa caucuses, throwing the race into turmoil until Reagan regained the upper hand for good with a victory in New Hampshire.

Despite the fact that there was no incumbent competing for the GOP prize, polling of both national Republicans and New Hampshire Republicans remained remarkably static throughout calendar year 1979. Among national Republicans, Reagan "competed" with Ford for the top spot in the field; no active candidate surpassed 20 percent in the polls or came within 10 percentage points of Reagan. In the few New Hampshire surveys conducted in 1979, Reagan's support remained at 40 percent. By October 1979, Bush had succeeded in reaching the 10-percent mark in New Hampshire, but still trailed Baker for second place (Figure 2).

As with the Democrats in 1979, early polling in New Hampshire yielded no special insights into the Republican race, compared to surveys of the national primary electorate. Both New Hampshire polls and national 
Figure 2. 1980 Republican Primary

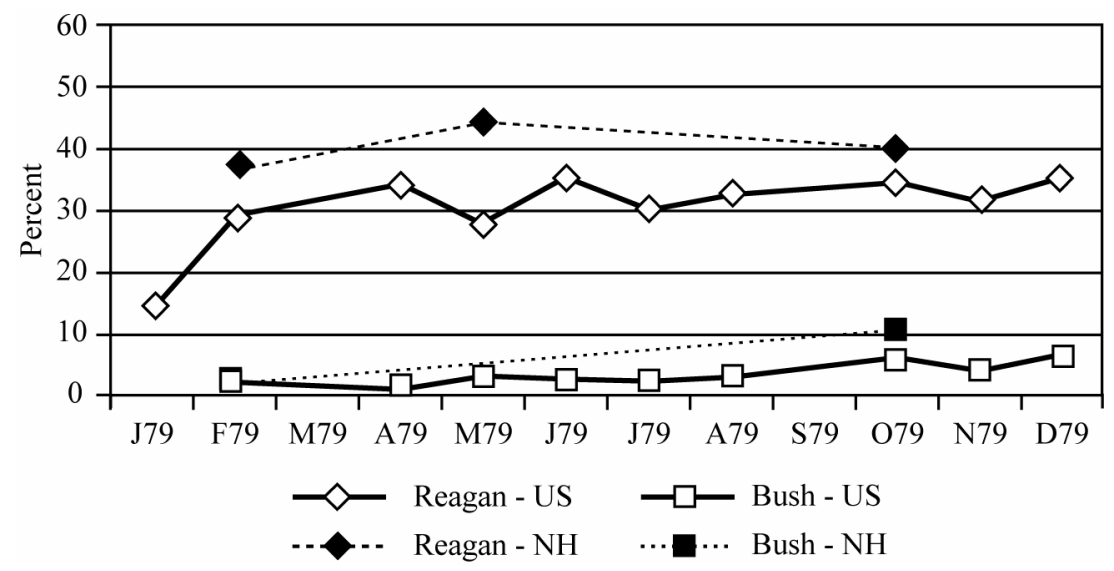

polls pointed to Reagan as the eventual winner of the Granite State primary and as the eventual nominee. National polling did lag slightly behind New Hampshire polling, but not to a significant degree. New Hampshire polling also failed to identify Bush as the main alternative to Reagan, though Bush had risen to third by the end of the calendar year.

\section{Democratic Primary}

In 1983, former vice president Walter Mondale was the clear choice of the Democratic Party establishment to attempt to unseat President Ronald Reagan in the general election. His main opponent for the nomination appeared to be Ohio Senator (and former astronaut) John Glenn. A host of candidates crowded the second tier of the race, including Colorado Senator Gary Hart and African-American political activist Rev. Jesse Jackson.

The 1984 nomination season turned out to be an intense, prolonged battle for Mondale, though his main opposition came from an unexpected source. Glenn's campaign never succeeded in getting on track, and the candidate quickly faded after poor showings in Iowa and New Hampshire. Hart, however, swung into contention with a surprising second-place finish in Iowa and a shocking triumph in New Hampshire. He became the chief alternative to Mondale for the nomination, only succumbing in the very last contests of the season.

There was little advance notice of the battle to come, however, in preprimary year polls during 1983. As in 1979 pre-primary polls, public opinion both nationally and in New Hampshire is noteworthy for its static nature. 
Figure 3. 1984 Democratic Primary

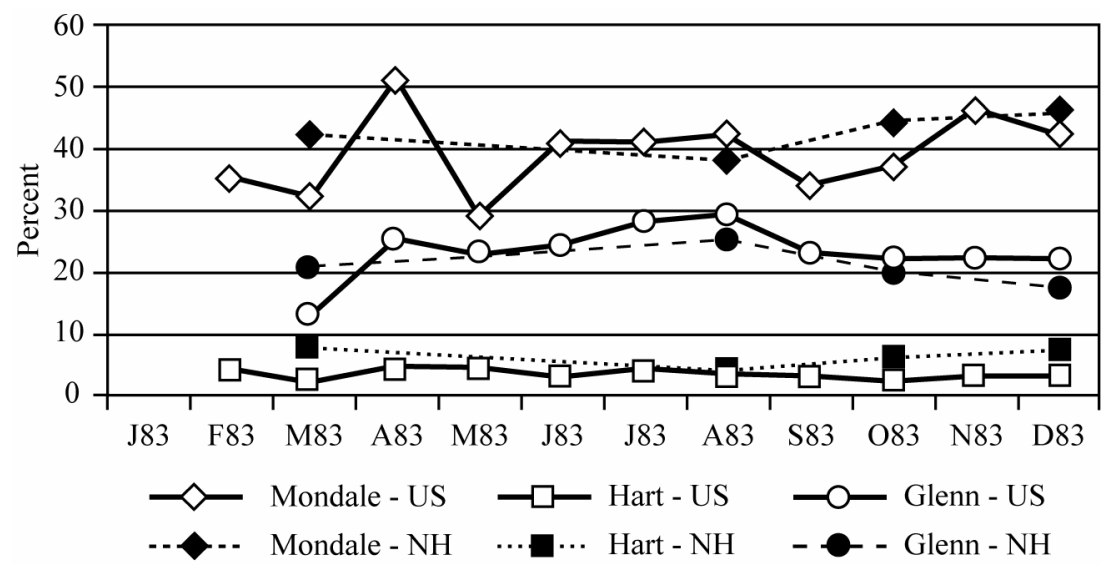

Nationally, Mondale climbed to 40 percent support in the spring and hovered at or above that for the rest of the calendar year. He maintained a lead over Glenn, who bounced between 20 and 30 percent. Jackson was the only other candidate in the field who managed to reach double-digit support nationally (Figure 3).

Movement in New Hampshire polling was similarly placid, showing no indication of the upset to come. Mondale remained at or about 40 percent in the several polls taken throughout 1983. Glenn remained in second place, although he showed clear signs of decline in the fall. And Hart, who carried 37 percent of the vote on Primary Day, did not manage to break into double digits in 1983.

Given the still waters of 1983 , perhaps it is unsurprising that New Hampshire polling picked up no indications of early movement in the race for the nomination. Quite possibly, there were no indicators to be detected. As in 1980, we find no evidence for any of our hypotheses that New Hampshire polling was any better than national polling at detecting early movement in the race for the nomination. Once again, New Hampshire polling did not even manage to identify the winner of the New Hampshire primary prior to national polling in the pre-primary year, although Hart did stand in third place in the Granite State at the end of 1983. 


\section{Democratic Primary}

In 1987, Gary Hart began the race for the Democratic nomination as the apparent frontrunner. His campaign, however, imploded in the spring under the weight of allegations of an extramarital affair, and the candidate left the race, only to reenter in late fall. For most of the year, however, the race for the nomination was left to a lesser-known group of Democrats derisively referred to as the "Seven Dwarfs."

In national polling, Democratic voters displayed various shades of ambivalence toward the contenders throughout calendar year 1987. Excluding Hart, only one candidate, Jesse Jackson, gained more than 20 percent support. Jackson eventually emerged as the main alternative to Massachusetts Governor Michael Dukakis, whose standing in national polls did not spike until the primaries began in winter 1988 (Figure 4).

Whereas national polling showed the race in a muddle, early surveys in New Hampshire indicated a contest that was much more clear-cut. Dukakis, the next-door neighbor from Massachusetts, was voters' chief alternative to Hart as early as winter 1987. After Hart departed the race, Dukakis dominated in the Granite State, scoring as high as 50 percent of the vote.

All told, New Hampshire polls in the calendar year prior to the 1988 primaries showed significant movement in the race for Dukakis, long before national polling detected any such movement. Unlike 1979 and 1983, New Hampshire surveys and surveys of the national Democratic primary electorate were clearly out of sync. New Hampshire polling detected significant movement toward Dukakis long before national polling picked up such

Figure 4. 1988 Democratic Primary

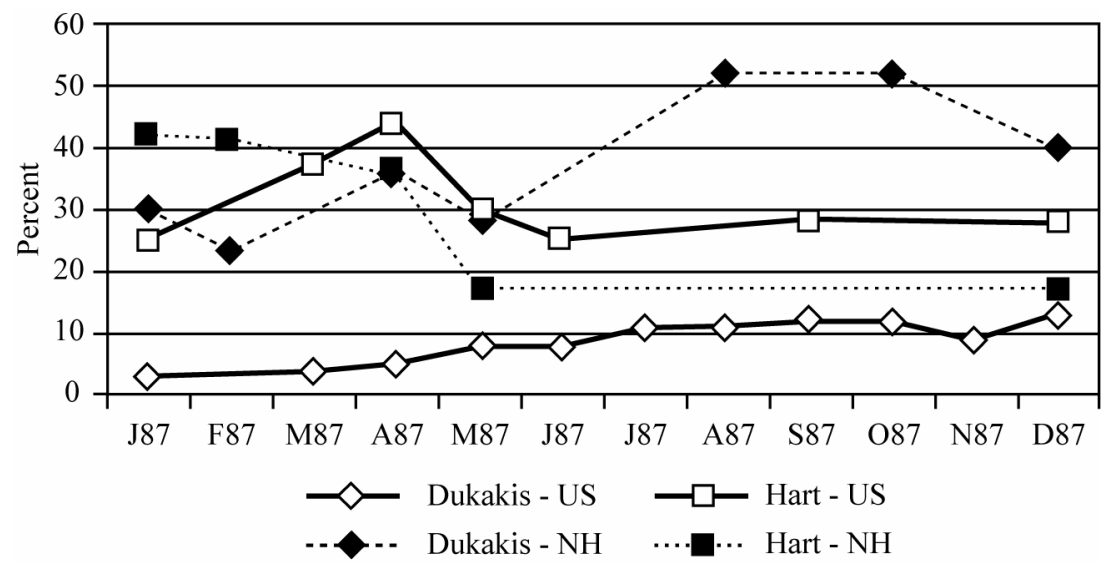


signs. Does this represent a "sea change" in the relative value of early polling in New Hampshire? Or was New Hampshire polling skewed by the fact that Dukakis was the governor next door in neighboring Massachusetts?

\section{Republican Primary}

In contrast to the Democrats' open scrum, polling of the Republican primary field was remarkably stable throughout calendar year 1987, both in New Hampshire and nationally. After a dip in winter 1987, Vice President George H. W. Bush maintained roughly 40 percent support in national polls for most of the calendar year. His standing in New Hampshire polls mirrored his national position. Similarly, Kansas Senator Bob Dole began and concluded 1987 as Bush's main challenger, both nationally and in New Hampshire (Figure 5).

Given this stability, it will come as no surprise that this particular case offers no compelling evidence of the value of New Hampshire polling as an early indicator of things to come in the presidential nomination season. Both New Hampshire polls and national polls point to Bush as the frontrunner and Dole as his main challenger. Bush does open up a larger lead in New Hampshire than he does nationally, but such evidence in favor of the hypothesis is slim at best.

Figure 5. 1988 Republican Primary

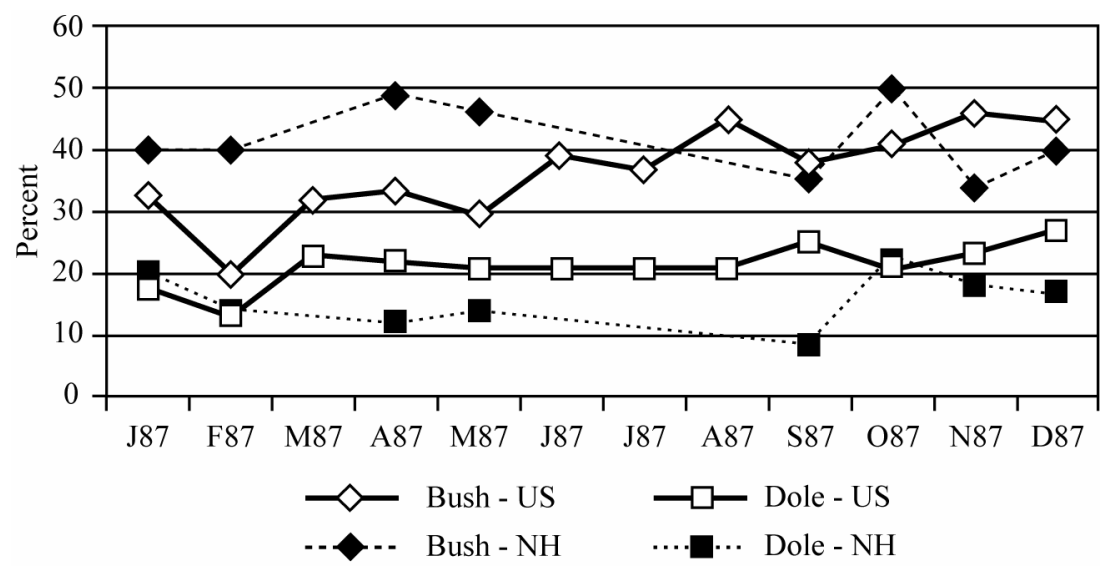




\section{Democratic Primary}

The Democrats, now out of the White House for more than a decade, appeared to face exceedingly bleak prospects for reclaiming it in 1991. Having successfully prosecuted a war in the Middle East, President George H.W. Bush stood sky-high in public opinion polls and appeared invulnerable. In the face of very dubious prospects of success, several prominent Democrats passed on pursuing the nomination of their party.

The most prominent of those who passed, New York Governor Mario Cuomo, led in national and New Hampshire polls throughout 1991. Beneath Cuomo, the only serious contender for the nomination who gained traction in early polling was the former governor of California, Jerry Brown. Indeed, Brown was the only candidate who reached double-digit support nationally by the end of the calendar year; Arkansas Governor Bill Clinton was just below 10 percent, and former Massachusetts Senator Paul Tsongas lower still (Figure 6).

Cuomo also dominated the few early polls in New Hampshire for much of 1991. Tsongas led the first New Hampshire poll (taken in December 1991) that left Cuomo out of the equation - a forecast of strength on Primary Day in the Granite State.

To sum up, pre-primary year polling in New Hampshire did succeed in identifying Tsongas as the eventual winner of the primary. In addition, Granite State polling noted a significant bump in Tsongas's support before national polling did, although it did not detect popular movement toward Bill Clinton in 1991.

Figure 6. 1992 Democratic Primary

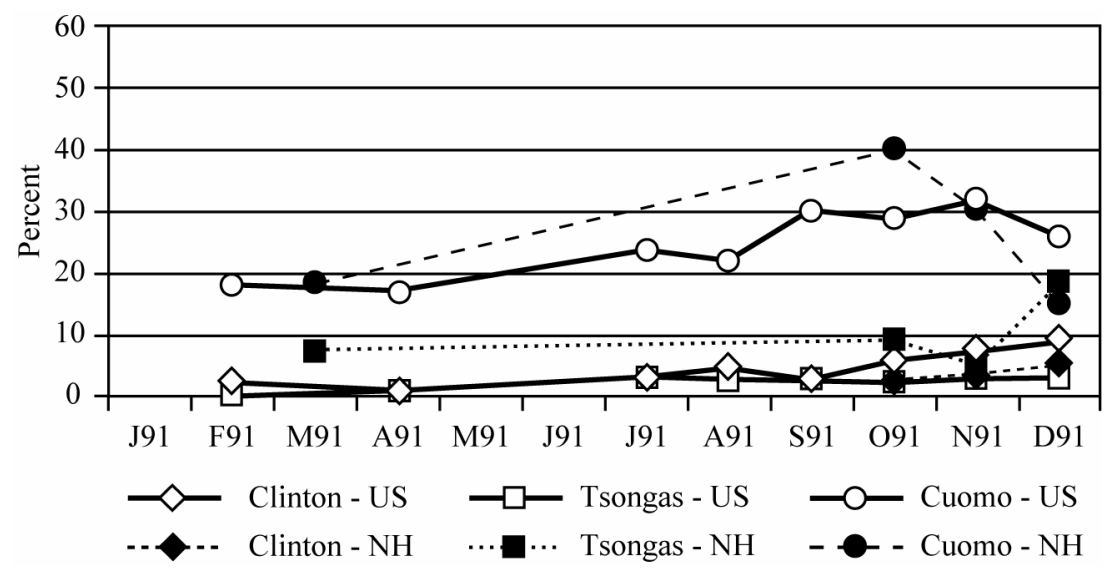




\section{Republican Primary}

Kansas Senator Bob Dole, a veteran of two failed attempts at the nomination, believed that on the third try it was his turn to lead the GOP in taking the White House back from President Bill Clinton. According to national polls during the pre-primary year of 1995, rank-and-file Republican voters tended to agree. Dole's support among Republicans nationally ranged from 40 to 50 percent all year. Of his challengers, only Texas Senator Phil Gramm managed to exceed 10 percent (Figure 7).

In New Hampshire polling, however, there were indications of potential weakness in Dole's candidacy. The Kansas senator peaked at 45 percent in mid-summer of 1995, but slumped to under 30 percent in November polling. Conservative activist and media commentator Patrick Buchanan, the eventual winner of the Granite State primary, briefly surged as high as 20 percent toward the end of 1995. Lamar Alexander, the former Tennessee governor and Secretary of Education who finished a close third in the primary, was only registering in high single digits by the end of the pre-primary calendar year.

During the pre-primary year, both national and New Hampshire surveys correctly identified Dole as the eventual nominee. Granite State polling, however, was quicker to pick up the significance of Buchanan's challenge to Dole, although it did not identify Buchanan as the eventual victor during the pre-primary year.

Figure 7. 1996 Republican Primary

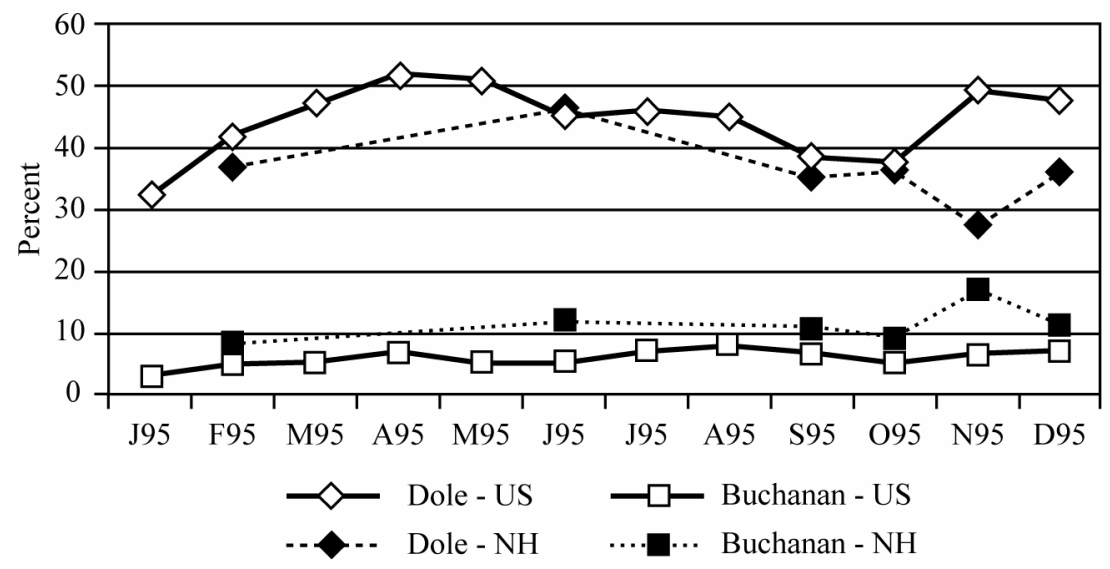




\section{Democratic Primary}

By early 1999, Vice President Al Gore had succeeded in clearing all but one potential competitor for the Democratic presidential nomination: former U. S. Senator Bill Bradley. Although the former New York Knickerbocker had been out of politics for several years, his insurgent campaign (coupled with a Democratic Party suffering from Clinton fatigue) had significant success raising funds.

National polls and New Hampshire polls tell two quite different stories of the competition between Gore and Bradley. In national polls of Democratic voters, Gore did not appear to be in serious danger for most of the year, keeping his support above 50 percent. Bradley's support remained in the 20-25 percent range, rising into the low 30s by the end of 1999 (Figure 8).

Polling in New Hampshire, however, indicated much more volatility among the electorate much earlier in the year. In the Granite State, the vice president dipped below 50 percent as early as June, and his support continued to droop to 40 percent in the fall of 1999. Bradley narrowed the gap with the frontrunner at the beginning of the summer, and pulled ahead of Gore by a narrow margin in some polling during the fall months.

Thus, for the fourth straight presidential nomination season, New Hampshire polling proved to be a more sensitive instrument for detecting significant early movement in the race for the nomination. Bradley emerged as a significant alternative to Gore in New Hampshire with much more force and velocity than he did in national polls.

Figure 8. 2000 Democratic Primary

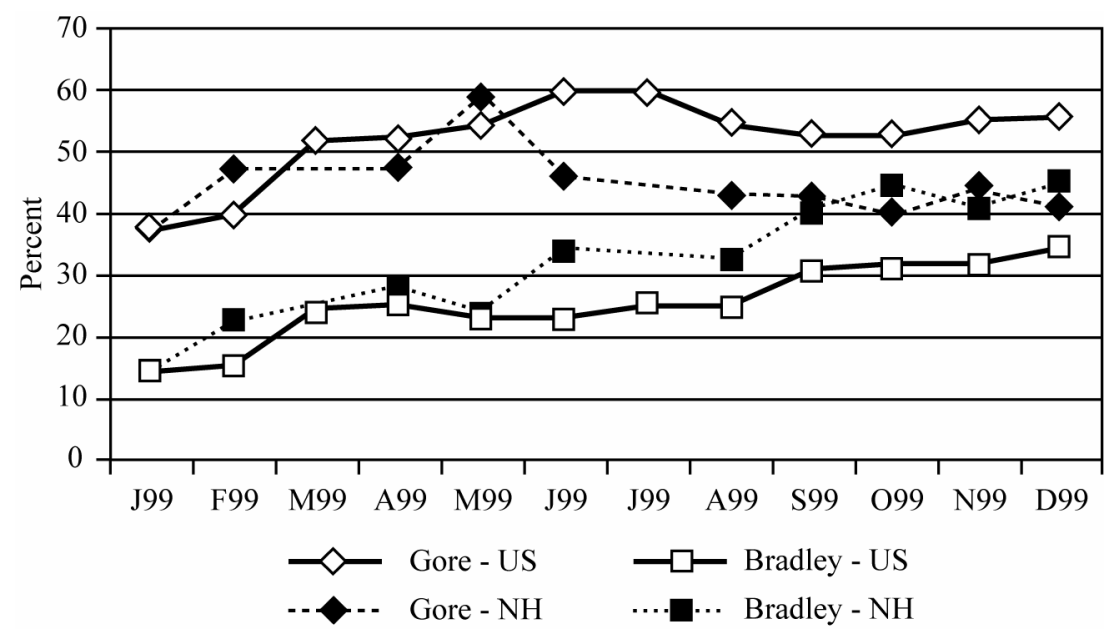




\section{Republican Primary}

Texas Governor George W. Bush, son of the former president, became the GOP establishment's choice to take back the White House from the Democrats in the months prior to the official opening of the nomination season. At first, he faced a large field that included former Cabinet secretary Elizabeth Dole; former Vice President Dan Quayle; and Lamar Alexander on his second try for the nomination. All three of these candidates, however, dropped out during the "invisible primary" of 1999. Once the dust settled, John McCain, U. S. Senator from Arizona, emerged as Bush's main opposition.

In many respects, national polling in 1999 mirrored the action on the Democratic side. Bush rose above 50 percent as early as March, and remained there throughout the year. McCain emerged as his chief opponent after Dole withdrew from the race at the end of the summer. But by the end of 1999, he had not yet succeeded in gaining even 20 percent support nationally (Figure 9).

Polling in New Hampshire, however, was much more volatile. Bush never succeeded in reaching 50 percent support in the Granite State, and his support slumped throughout the fall, reaching the low 30s. The McCain campaign, after treading water at the 10 percent mark for the spring and summer, sprang to life in the fall, quickly rising to nearly 40 percent and first place in the Granite State.

Figure 9. 2000 Republican Primary

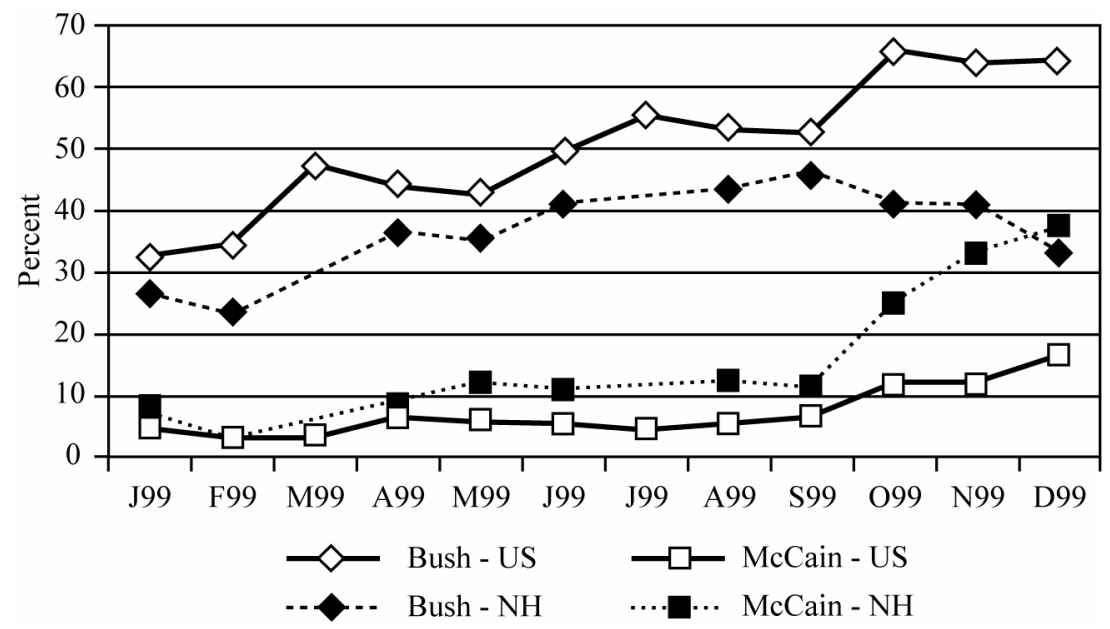


All in all, pre-primary year Republican polling in New Hampshire was a much more sensitive gauge of the force and velocity of McCain's "Straight Talk Express" than national polling proved to be. Autumn polling in the Granite State clearly pointed to McCain as Bush's chief competitor, while national polling placed the Arizona senator barely above third-place Steve Forbes. This piece of forecasting is especially impressive, given that multiple candidates were in play.

\section{Democratic Primary}

The 2004 nomination season began with 2000 vice presidential nominee Joseph Lieberman leading the field nationally. Nonetheless, conventional wisdom at the beginning of 2003 put Massachusetts Senator John Kerry at the front of the pack, followed by first-term North Carolina Senator John Edwards as the moderate, Southern alternative. Vermont Governor Howard Dean, however, made waves early with a fiery speech to the Democratic National Committee, promising that he would take the party back for the "Democratic wing of the Democratic Party."

Once again, New Hampshire polling proved a more sensitive barometer of movement in the race for the nomination. Nationally, there were only two significant movements in the polls: Lieberman's drop from first place, and Dean's late movement upward at the very end of 2003, when many observers thought his nomination was all but assured. Otherwise, the field resembled nothing so much as a stagnant pond in the national polls (Figure 10).

Figure 10. 2004 Democratic Primary

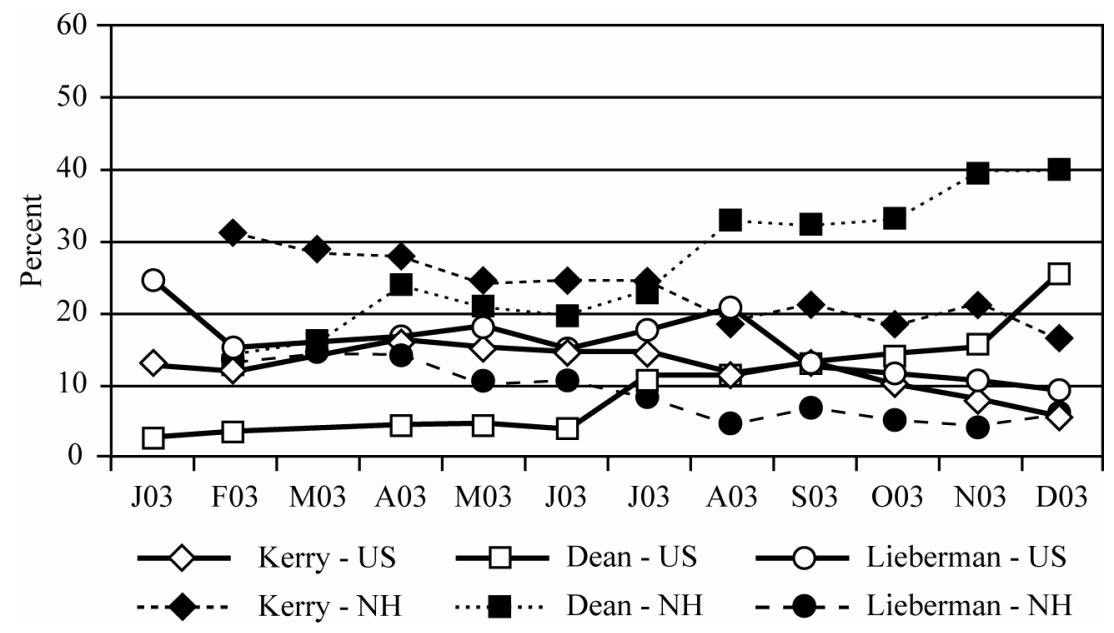


In New Hampshire, however, much more was afoot. During the year, Dean and Kerry clearly separated themselves from the pack of competitors. Kerry began strongly in the Granite State, and despite his slow fade throughout most of the calendar year, remained in second place at the end of 2003. Dean doubled his initial support by August, and reached the 40 percent mark by November.

Once again, New Hampshire polling in the pre-primary year proved to be a far better leading indicator than national surveys. Early polling in the Granite State clearly identified Dean and Kerry as main competitors for the nomination, while national surveys were much more indistinct in outlining the shape of the race. (It is worth noting, however, that North Carolina Senator John Edwards was mired in single digits in New Hampshire, just as he was nationally.) And once again, New Hampshire surveys picked up the force and velocity of Dean's campaign with a sensitivity lacking in the laggard national polls. ${ }^{13}$

\section{Democratic Primary}

The 2008 nomination process marks the first time in the modern primary era that neither an incumbent President nor Vice President is in the running. On the Democratic side, New York Senator and former First Lady Hillary Clinton was the prohibitive favorite in the eyes of the media and in national and New Hampshire polls. But she did not remain unchallenged for long. Illinois Senator Barack Obama jumped into the race in February 2007 and quickly proved that his fund-raising abilities were at least equal to Clinton's. And 2004 candidate (and vice presidential nominee) John Edwards was again running for the top of his party's ticket, although his campaign focused on Iowa more than New Hampshire (Figure 11).

While the Democratic race was stable throughout much of 2008, New Hampshire polls were more sensitive than national polls in showing changes in support for Obama as his campaign waxed and waned during the summer. And while it is too early to tell who the eventual nominee will be, New Hampshire polls detected a tightening race between Clinton and Obama long before national polls did. ${ }^{14}$

\section{Republican Primary}

The 2008 Republican nomination fight featured former New York mayor Rudy Giuliani as the early favorite nationally while John McCain, winner of the 2000 New Hampshire primary, led in early Granite State polls. Former Massachusetts governor Mitt Romney entered the race with special emphasis on New Hampshire and Iowa, hoping that early victories would 
quickly gain momentum and consolidation of conservative party regulars behind his candidacy (Figure 12).

New Hampshire polls clearly showed Giuliani's decline in late 2007 before it registered in national polls. Similarly, McCain's late spring drop (over his support for immigration legislation) and his later recovery in the

Figure 11. 2008 Democratic Primary

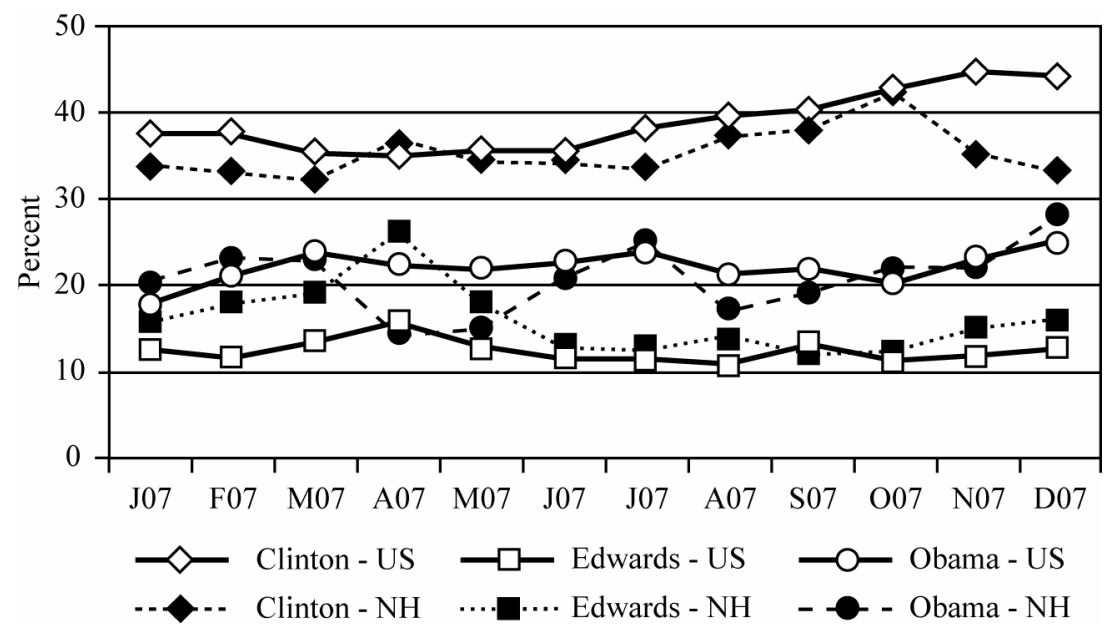

Figure 12. 2008 Republican Primary

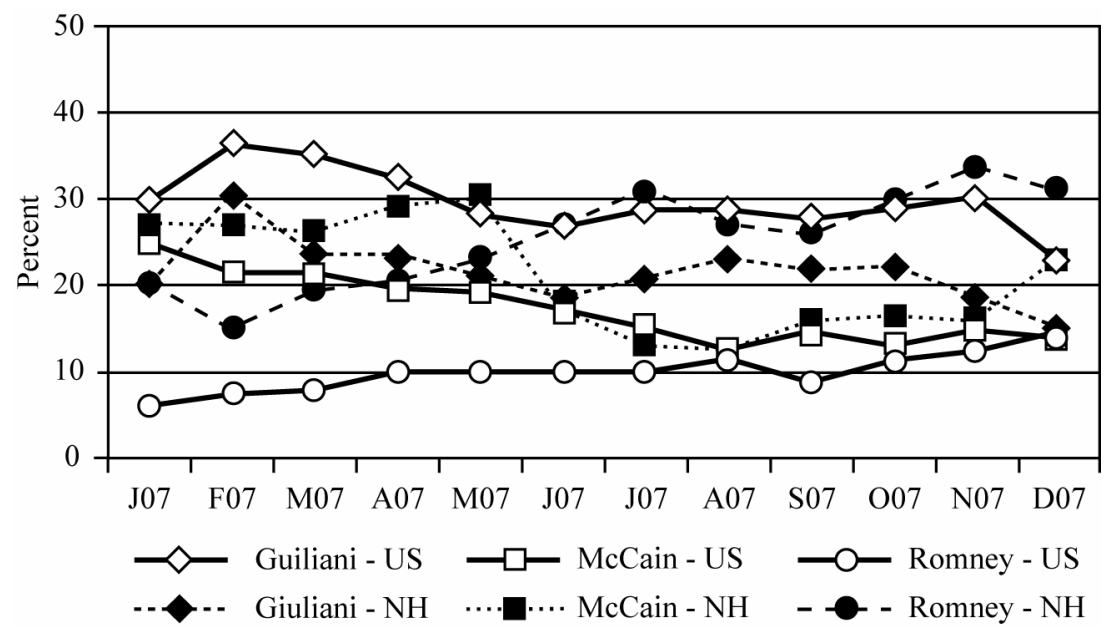


fall were both seen more clearly in New Hampshire first. And polls in New Hampshire registered the early effectiveness of the Romney campaign strategy of focusing on New Hampshire and counting on success here to translate into an improved national stature.

Although New Hampshire polls in December did not predict McCain as the winner, they clearly showed his steady improvement, Giuliani's decline, and the plateau and eventual decline of Romney well before national polls. ${ }^{15}$

\section{Conclusions}

Dick Morris, commentator and former political advisor to Bill Clinton and Trent Lott, recently wrote that early national polls are a better gauge for determining the eventual 2008 nominees than polls in the early primary states:

Traditionally, national polls have not been worth the cost of printing them. They typically show the better-known national candidates in the lead and fail to capture the local appeal of a lesser-known candidate who is quietly winning converts in the early-primary and caucus states. In the past, as the candidates campaigned extensively in the early states, voters there came to know them very well and their reactions often presaged those of the rest of the country once America began to focus on the race. In prior years, the results in Iowa and New Hampshire imposed themselves on the nation, sometimes sweeping aside the candidates who had been designated as front-runners in the national surveys (Morris, 2007; emphasis added).

Our study of early national and New Hampshire polling suggests that Morris is guilty of some hyperbole here. From 1980 to 2008, we cannot point to a single instance when voters' decisions in Iowa and New Hampshire "swept aside" the national frontrunner. (One might point to the dethroning of Howard Dean as one such example, but the former Vermont Governor was a very late, very weak national frontrunner in 2003 polling.)

Our study, however, does indicate that New Hampshire polling has indeed become more and more prescient in recent nomination seasonsespecially when it comes to naming the chief challenger / insurgent to the frontrunner. Time and again since 1992, New Hampshire surveys have picked up early (i.e., pre-primary) surges in support for candidates who were not frontrunners-Tsongas; Buchanan; Bradley; McCain; and Dean. These surges proved to be significant and permanent, inasmuch as the candidate who surged early in New Hampshire eventually became the main alternative to the frontrunner. In this sense, Granite State surveys have behaved as leading indicators for the last several nomination cycles, detecting movement by candidates who only later make an impact on national polls. 


\section{Table 2. Results of Hypothetical Testing}

$\mathbf{H}_{1}$ : New Hampshire polls will identify the winner of the New Hampshire primary before national polls.

$\mathbf{H}_{2}$ : New Hampshire polls will identify the eventual winner of the nomination before national polls.

$\mathbf{H}_{3}$ : National polls will lag behind New Hampshire polls, that is, a candidate will move up or down in trial heats in New Hampshire before they move up or down in national polls.

$\mathbf{H}_{4}$ : New Hampshire polls will identify the main alternative to the eventual winner of the nomination before national polls.

\begin{tabular}{lcccc}
\hline & $\mathbf{H}_{\mathbf{1}}$ & $\mathbf{H}_{\mathbf{2}}$ & $\mathbf{H}_{\mathbf{3}}$ & $\mathbf{H}_{\mathbf{4}}$ \\
\hline $1980 \mathrm{D}$ & $\mathrm{N}$ & $\mathrm{N}$ & $\mathrm{N}$ & $\mathrm{N}$ \\
$1980 \mathrm{R}$ & $\mathrm{N}$ & $\mathrm{N}$ & $\mathrm{N}$ & $\mathrm{N}$ \\
$1984 \mathrm{D}$ & $\mathrm{N}$ & $\mathrm{N}$ & $\mathrm{N}$ & $\mathrm{N}$ \\
$1988 \mathrm{D}$ & $\mathrm{Y}$ & $\mathrm{Y}$ & $\mathrm{Y}$ & $\mathrm{N}$ \\
$1988 \mathrm{R}$ & $\mathrm{N}$ & $\mathrm{N}$ & $\mathrm{Y}$ & $\mathrm{N}$ \\
$1992 \mathrm{D}$ & $\mathrm{Y}$ & $\mathrm{N}$ & $\mathrm{Y}$ & $\mathrm{Y}$ \\
$1996 \mathrm{R}$ & $\mathrm{N}$ & $\mathrm{N}$ & $\mathrm{Y}$ & $\mathrm{Y}$ \\
$2000 \mathrm{D}$ & $\mathrm{N}$ & $\mathrm{N}$ & $\mathrm{Y}$ & $\mathrm{Y}$ \\
$2000 \mathrm{R}$ & $\mathrm{Y}$ & $\mathrm{N}$ & $\mathrm{Y}$ & $\mathrm{Y}$ \\
$2004 \mathrm{D}$ & $\mathrm{N}$ & $\mathrm{Y}$ & $\mathrm{Y}$ & $\mathrm{Y}$ \\
N CORRECT & 3 & 2 & 7 & 5 \\
$\%$ CORRECT & $30 \%$ & $20 \%$ & $70 \%$ & $50 \%$ \\
1992 ON: N CORRECT & 2 & 1 & 5 & 5 \\
1992 ON: \% CORRECT & $40 \%$ & $20 \%$ & $100 \%$ & $100 \%$ \\
\hline
\end{tabular}

The idea that winning in New Hampshire and Iowa can propel a candidate to the nomination has led many candidates to concentrate their campaign efforts on those states. The New Hampshire strategy was behind the successful nominations of former Massachusetts governor Michael Dukakis (1988), George H.W. Bush (1988), and the attempt of Howard Dean (2004). Jimmy Carter (1976), Robert Dole (1988 and 1996), Dick Gephardt (1988 and 2004), and John Kerry (2004) relied on an Iowa strategy to win them the nomination. But Dick Morris argues that 2008 is different.

With public interest in the presidential campaign at dizzying levels, not just in the early-primary or caucus states where candidates are concentrating their campaigns but throughout the nation, the opinions voters express in national polls are not nearly as ill-informed or tentative as in past elections. With cable news channels covering the early running with breathless intensity, 
voters outside the early states are forming definite opinions, often quite contrary to those which predominate in early state polls. Since at least 10 states have moved their primaries to February 5 and most are likely to follow, it would stand to reason that this year voters are concentrating on the choices earlier than they have in previous years, so the national polls may mean more than they have in the past.

Although as of this writing the nominations are not yet decided, we do know that candidates' standings in the national polls did not mean more than they have in the past. This is especially clear on the Republican side. Giuliani, the leader in national polls during 2007, eventually departed the race without winning a single primary. Another candidate who downplayed the importance of early contests, former Tennessee senator Fred Thompson, met a similar fate. The final two contestants for the nomination, former Arkansas governor Mike Huckabee and John McCain, were the winners of Iowa and New Hampshire, respectively. Early New Hampshire polling did capture McCain's surge in December 2007, though Romney still led in the Granite State in December.

On the Democratic side, national polling and New Hampshire polling mirrored each other to a much greater degree. The two top candidates in national polling, Clinton and Obama, are the two candidates still remaining in the race for the nomination. Obama won the Iowa caucuses and Clinton responded with a victory in the New Hampshire primary. Granite State polling did detect a tightening of the race between Clinton and Obama, while concurrent national polling indicated a double-digit lead for Clinton.

All in all, despite the heightened attention paid nationally to the nomination contests this cycle, a central tenet of our argument remains intact: New Hampshire polls, conducted in a state where voters receive far more news about the candidates and pay a great deal of attention to the campaign, are much more sensitive to changes in the dynamics of the nomination contest than national surveys.

\section{NOTES}

${ }^{1}$ http://firstread.msnbc.msn.com/archive/2007/08/06/305724.aspx

${ }^{2}$ http://firstread.msnbc.msn.com/archive/2007/08/06/305863.aspx

${ }^{3}$ We do not claim that this list of polls is inclusive. We would appreciate any additional data points that could be included in subsequent analyses. We excluded the 1992 Republican contest because it developed so late in 1991; very few national or New Hampshire polls of the race were conducted.

${ }^{4}$ Organizations conducting National and New Hampshire Polls included ABC, APIPSOS, Boston Globe, Boston Herald, CBS, CNN, Franklin Pierce College, FOX, Gallup, Harris, Los Angeles Times, New York Times, Newsweek, Pew, Time, Times Mirror, Rasmussen, Suffolk University, USA Today, University of New Hampshire, 
Washington Post, WBZ-TV, Boston MA, WCVB-TV, Boston MA, WMUR-TV, Manchester $\mathrm{NH}$; and combinations of the above.

${ }^{5}$ SurveyUSA conducts computer generated surveys that do not use live interviewers. While there is some evidence that polls conducted in this method are accurate gauging elections immediately before the election, there has been no research examining their sensitivity or insensitivity to campaign dynamics. Harris Excite conducts internet based surveys from panels that are randomly selected from the general population by traditional RDD methods. Taylor et al. (2001) argue that Harris Interactive's pre-election polls in 2000 were quite accurate.

${ }^{6}$ See Patterson (2005) about the proliferation and use of election polls.

${ }^{7}$ http://www.americanresearchgroup.com/nhpoll/ primary.

${ }^{8}$ See Smith (2004) for a discussion of problems with polling in the New Hampshire

${ }^{9}$ See Crespi (1988), Perry (1973 and 1979), Dimock et al. (2001) about the importance of identifying likely voters and the accuracy of different likely voter models.

${ }^{10}$ See Bishop (2005) for a discussion of non-attitudes and the impact of question form effects.

${ }^{11}$ It is not known if the names of the candidates were rotated to minimize response order effects.

${ }^{12}$ Taking the monthly average also should aid in controlling any potential heteroskedasticity resulting from the use of increasing numbers of polls over time.

${ }^{13} 2003$ marked the first time that New Hampshire primary polling was done in each of the 12 months of the calendar year. Thus we were able to run correlations of candidates' standings in New Hampshire polls and national polls month by month for the entire year. For Howard Dean, the correlation between his New Hampshire poll numbers and national poll numbers stood at .85 , significant at the .01 level. The same correlation, with a month's lag time between Dean's New Hampshire numbers and his national numbers (e.g., correlating Dean's June numbers in New Hampshire and his July numbers nationally) yielded a slightly better correlation of .88, significant at the .01 level. For John Kerry, the correlation between his New Hampshire numbers and national poll numbers was also quite strong at .88 , significant at the .01 level. When we lagged the national numbers by one month, the correlation dropped to .75 , significant at the .05 level.

${ }^{14}$ Correlations of candidates' standings in New Hampshire and national polls showed varying results. On the one hand, lagging Hillary Clinton's national poll numbers one month behind her New Hampshire poll standings improved the correlation from .36 to .64 (the latter was significant at the .05 level). On the other, the correlations for John Edwards and Barack Obama decreased with the lag; Edwards's correlations declined from .79 (significant at the .01 level) to .46 with the lag. Obama's correlations declined from .45 to .14 .

${ }^{15}$ Correlations of these candidates' standings in New Hampshire and national polls showed some support for the hypothesis. The correlation between Mitt Romney's New Hampshire and national poll numbers was significant with and without the one-month national lag (.89 without lag; .77 with lag; both significant at the .01 level). The correlation for John McCain increased significantly when the lag was added (.40 without lag; .62 with lag, significant at the .05 level). For Rudy Giuliani, the correlation decreased significantly when the lag was added (.79 without lag, significant at the .01 level; .30 with lag). This decrease is explained by Giuliani's drop in New Hampshire polls at the end of 2007, a portent of his drop in national polls in early 2008. 


\section{REFERENCES}

Adams, William. 1987. As New Hampshire Goes ... In Media and Momentum, ed. Gary R. Olsen and Nelson W. Polsby. Chatham, NJ: Chatham House.

Adkins, Randall, and Andrew Dowdle. 2000. Break out the Mint Juleps in New Hampshire: A Forecasting Model of the Presidential Primaries. American Politics Quarterly 28:251-269.

Adkins, Randall, and Andrew Dowdle. 2001. How Important are Iowa and New Hampshire to Winning Post-Reform Presidential Nominations? Political Research Quarterly 54:431-444.

Aldrich, John. 1980. A Dynamic Model of Presidential Nomination Campaigns. American Political Science Review 74:651-669.

Bartels, Larry. 1988. Presidential Primaries and the Dynamics of Public Choice. Princeton, NJ: Princeton University Press.

Bishop, George. 2005. The Illusion of Public Opinion: Fact and Artifact in American Public Opinion Polls. Lanham, MD: Rowman and Littlefield.

Crespi, Irving. 1988. Pre-Election Polling: Sources of Accuracy and Error. New York: Russell Sage Foundation.

Dimock, Michael, Scott Keeter, and Mark Schulman. 2001. Screening for Likely Voters in Pre-Election Surveys: A Voter Validation Experiment. Paper presented at the annual meeting of the American Association for Public Opinion Research, May 2001, Montreal.

Erickson, Robert, Costas Panagopoulos, and Christopher Wlezien. 2004. Likely and Unlikely Voters and the Assessment of Campaign Dynamics. Public Opinion Quarterly 68:589-601.

John, Kenneth. 1989. The Polls-A Report: 1980-1988 New Hampshire Presidential Primary Polls. Public Opinion Quarterly 53:590-605.

Keeter, Scott, and Cliff Zukin. 1984. Uninformed Choice: The Failure of the New Presidential Nominating System. New York: Praeger.

Lichter, S. Robert, Daniel Amundson, and Richard Noyes. 1988. The Video Campaign: Network Coverage of the 1988 Primaries. Washington DC: American Enterprise Institute.

Marshall, Thomas. 1983. Evaluating Presidential Nominees: Opinion Polls, Issues, and Personalities. Western Political Quarterly 36:450-659.

Mayer, William. 1996. Forecasting Presidential Nominations. In In the Pursuit of the White House 2000, ed. William Mayer. Chatham, NJ: Chatham House.

Mayer, William 2004. The Basic Dynamics of the Contemporary Nomination Process: An Expanded View. In The Making of the Presidential Candidates 2004, ed. William Mayer. Lanham, MD: Rowman and Littlefield.

McDermott, Monica, and Kathleen Francovic. 2003. Horserace Polling and Survey Method Effects: An Analysis of the 2000 Campaign. Public Opinion Quarterly 67:245-264.

Miller, Joanne, and John Krosnick. 1998. The Impact of Candidate Name Order on Election Outcomes. Public Opinion Quarterly 62:291-330.

Morris, Dick. 2007. National vs. Local Trends. www.TheHill.com, May 30, 2007.

Norrander, Barbara. 1986. Correlates of Vote Choice in the 1980 Presidential Primaries. Journal of Politics 38:156-167.

Patterson, Thomas. 2005. Of Polls, Mountains: U.S. Journalists and Their Use of Election Surveys. Public Opinion Quarterly 69:716-724. 
Perry, Paul. 1973. A Comparison of the Voting Preferences of Likely Voters and Likely Non-Voters. Public Opinion Quarterly 37:99-109.

Perry, Paul 1979. Certain Problems in Election Survey Methodology. Public Opinion Quarterly 43:312-325.

Rademacher, Eric, Andrew Smith, Thomas Shaw, and Alfred Tuchfarber. 2001. Ballot Order and Candidate Preference in Pre-Election Telephone Surveys. Paper presented at the annual meeting of the American Association for Public Opinion Research, May 2001, Montreal.

Smith, Andrew. 2004. The Perils of Polling in New Hampshire. In The Making of the Presidential Candidates 2004, ed. William Mayer. Lanham, MD: Rowman \& Littlefield.

Steger, Wayne. 2002. A Quarter Century of Network News Coverage of Candidates in Presidential Nomination Campaigns. Journal of Political Marketing 1:91-116.

Taylor, Humphrey, John Brenner, Cary Overmeyer, Jonathan Siegel, and George Terhanian. 2001. Touchdown!: Online Polling Scores Big in November 2006. Public Perspective 12(2):38-39. 